\title{
In-pile Hydrothermal Corrosion Evaluation of Coated SiC Ceramics and Composites
}

Nuclear Technology

Research and Development

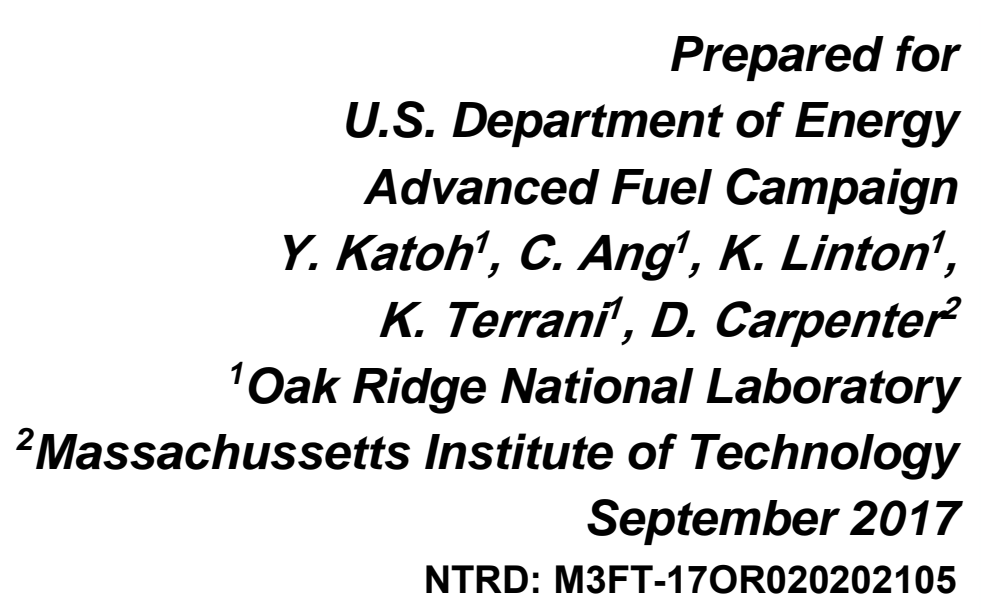





\section{DISCLAIMER}

This information was prepared as an account of work sponsored by an agency of the U.S. Government. Neither the U.S. Government nor any agency thereof, nor any of their employees, makes any warranty, expressed or implied, or assumes any legal liability or responsibility for the accuracy, completeness, or usefulness, of any information, apparatus, product, or process disclosed, or represents that its use would not infringe privately owned rights. References herein to any specific commercial product, process, or service by trade name, trade mark, manufacturer, or otherwise, does not necessarily constitute or imply its endorsement, recommendation, or favoring by the U.S. Government or any agency thereof. The views and opinions of authors expressed herein do not necessarily state or reflect those of the U.S. Government or any agency thereof. 



\section{SUMMARY}

Hydrothermal corrosion accelerated by water radiolysis during normal operation is among the most critical technical feasibility issues remaining for silicon carbide (SiC) composite-based cladding that could provide enhanced accident-tolerance fuel technology for light water reactors. An integrated in-pile test was developed and performed to determine the synergistic effects of neutron irradiation, radiolysis, and pressurized water flow, all of which are relevant to a typical pressurized water reactor (PWR). The test specimens were chosen to cover a range of $\mathrm{SiC}$ materials and a variety of potential options for environmental barrier coatings. This document provides a summary of the irradiation vehicle design, operations of the experiment, and the specimen loading into the irradiation vehicle. 
In-pile Hydrothermal Corrosion Evaluation of Coated SiC Ceramics and Composites

INTENTIONALLY BLANK 


\section{CONTENTS}

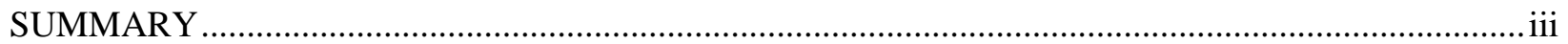

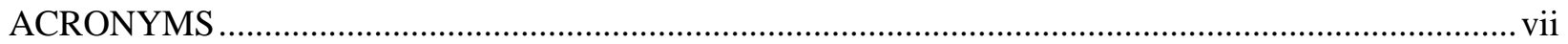

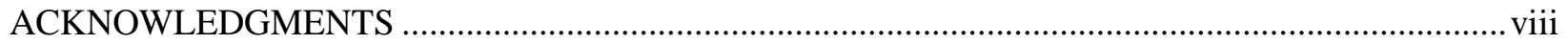

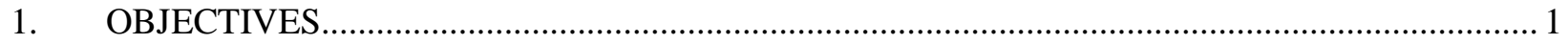

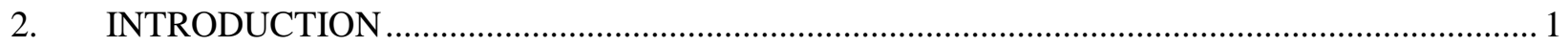

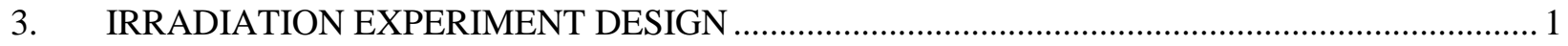

3.1 Description of the MIT Research Reactor...................................................................... 1

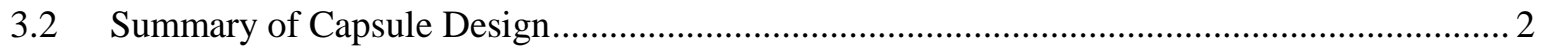

3.3 Experiment Test Plan Materials …............................................................................... 3

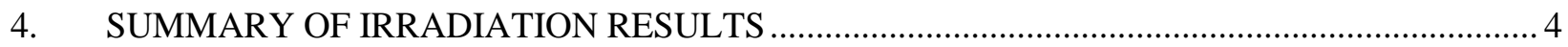

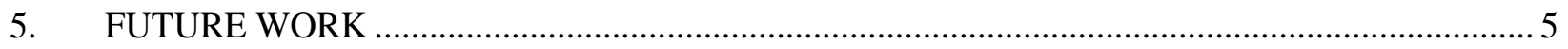

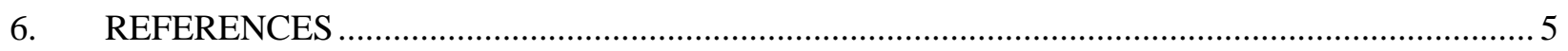

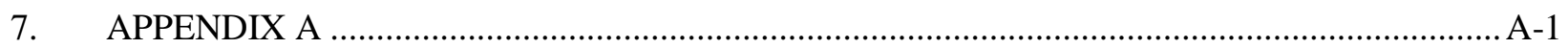

\section{FIGURES}

Figure 1 - Illustration of irradiation vehicles: Modules 3, 6, and 9 for tubular specimens (left) and Modules 4, 7, and 10 for coupon specimens (right). ............................................................ 2

Figure 2 - COATI in- and above-core capsule locations within the autoclave stack................................ 3

\section{TABLES}

Table 1 - Summary of irradiation vehicles for this experiment …........................................................ 2

Table 2 - Specimen Summary by Location, Module and Type ……...................................................... 3

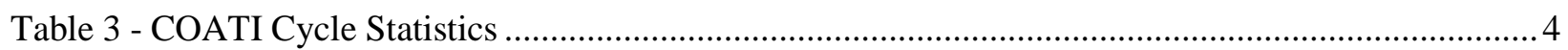

Table 4 - Adjusted Neutron Fluence for ORNL Capsules ................................................................. 5 
In-pile Hydrothermal Corrosion Evaluation of Coated SiC Ceramics and Composites 


\section{ACRONYMS}

ATF accident tolerant fuel

AFC Advanced Fuels Campaign

COATI ORNL Hybrid Composites Loop ATF Irradiation

DOE-NE US Department of Energy Office of Nuclear Energy

EBC environmental barrier coatings

LWR light water reactor

MIT Massachusetts Institute of Technology

MITR Massachusetts Institute of Technology Nuclear Reactor Laboratory's Research Reactor

NTRD Nuclear Technology Research and Development

ORNL Oak Ridge National Laboratory

PWR pressurized water reactor

$\mathrm{SiC} / \mathrm{SiC}$ silicon carbide continuous fiber-reinforced silicon carbide matrix

$\mathrm{SiC} \quad$ silicon carbide $(\mathrm{SiC})$ 


\section{ACKNOWLEDGMENTS}

This work was supported by the US Department of Energy Office of Nuclear Energy (DOE-NE) Advanced Fuels Campaign (AFC). The authors thank Chirs Petrie for a technical review of the manuscript. 


\section{OBJECTIVES}

Silicon carbide $(\mathrm{SiC})$ continuous fiber-reinforced $\mathrm{SiC}$ matrix ( $\mathrm{SiC} / \mathrm{SiC})$ composite-based fuel cladding is considered a leading candidate among the enhanced accident-tolerant fuel (ATF) technologies for light water reactors for a number of reasons including exceptional high temperature stability and slow kinetics for steam oxidation in beyond-design basis accident conditions [1-3]. However, hydrothermal corrosion during normal operation is among the most critical technical feasibility issues remaining for SiCbased fuel cladding for light water reactor (LWR) applications [4,5]. This is particularly the case since water radiolysis is now known to accelerate the hydrothermal corrosion of $\mathrm{SiC}$ at LWR-relevant temperatures [5,6]. To address this issue, integrated in-pile tests must be conducted that combine the key elements of the normal operating environment for LWR fuels: mixed thermal and fast spectrum neutrons, flowing water of relevant chemistry at a relevant temperature, and ionizing radiation capable of radiolysis of water. The objective of the work reported in this document is to design, implement, and perform an experiment that allows exposure of test specimens in such an integrated environment.

\section{INTRODUCTION}

This report details the design, development, and operation of an in-pile hydrothermal corrosion experiment that is being conducted in support of the Light Water Reactor (LWR) Core Materials, Advanced Fuels Campaign (AFC), which is funded by the Nuclear Technology Research and Development (NTRD) Program of the Office of Nuclear Energy, US Department of Energy. In this activity, irradiation vehicles were designed to allow exposure of a large number of test specimens to both neutrons and ionizing radiation in a water loop that simulates coolant conditions of a pressurized water reactor (PWR) (relevant water chemistry and temperature) in the Massachusetts Institute of Technology (MIT) Nuclear Reactor Laboratory's Research Reactor (MITR). Researchers at Oak Ridge National Laboratory (ORNL) designed the specimen matrix to allow evaluation of bulk silicon carbide (SiC) (varied quality), continuous $\mathrm{SiC}$ fiber-reinforced $\mathrm{SiC}$ matrix ( $\mathrm{SiC} / \mathrm{SiC}$ ) composites, and $\mathrm{SiC}$ ceramics and composites with various environmental barrier coatings (EBC). This document contains a brief description of the MIT Research Reactor, a description of the capsule design and specimen test matrix, and irradiation results. Complete records of irradiation vehicle fabrication and experimental operation are maintained at the MIT Nuclear Reactor Laboratory [7].

\section{IRRADIATION EXPERIMENT DESIGN}

\subsection{Description of the MIT Research Reactor}

The MIT Reactor (MITR) is a light-water cooled and moderated research reactor with in-core experimental facilities. The core consists of finned plate-type fuel elements which currently use highly enriched ${ }^{235} \mathrm{U}$ fuel with a core power density averaging $70 \mathrm{~kW}$ per liter. Heavy water surrounding the core reflects neutrons providing researchers with a maximum fast and thermal neutron flux of $1.2 \times 10^{14}$ and $6 \times 10^{13}$ neutrons $/ \mathrm{cm}^{2}$-s, respectively [7]. 


\subsection{Summary of Capsule Design}

Separate irradiation vehicles were designed to allow exposure to PWR loop water in a) an in-core position where specimens are exposed to high energy neutrons and water radiolysis products, b) an above-core position where specimens are exposed to water radiolysis products without significant neutron damage, and c) an out-of-core position without water radiolysis or neutron damage. The ORNL Hybrid Composites Loop ATF Irradiation was designated as "COATI" by the MITR. Table 1 summarizes the irradiation vehicles. The computer-aided design illustrations of the individual vehicles are shown in Figure 1 and the full length loop experiment is shown in Figure 2. Note that Modules 3, 6, and 9 are identical, and so are Modules 4, 7, and 10.

Table 1 - Summary of irradiation vehicles for this experiment

\begin{tabular}{|c|c|c|c|}
\hline Module \# & Position & Alias & Specimen Type \\
\hline 3 & In-core & In-core ORNL 1 & Tubes \\
\hline 4 & In-core & In-core ORNL 2 & Coupons \\
\hline 6 & Above-core & Above-core ORNL 1 & Tubes \\
\hline 7 & Above-core & Above-core ORNL 2 & Coupons \\
\hline 9 & Out-of-core & Out-of-core ORNL 1 & Tubes \\
\hline 10 & Out-of-core & Out-of-core ORNL 2 & Coupons \\
\hline
\end{tabular}

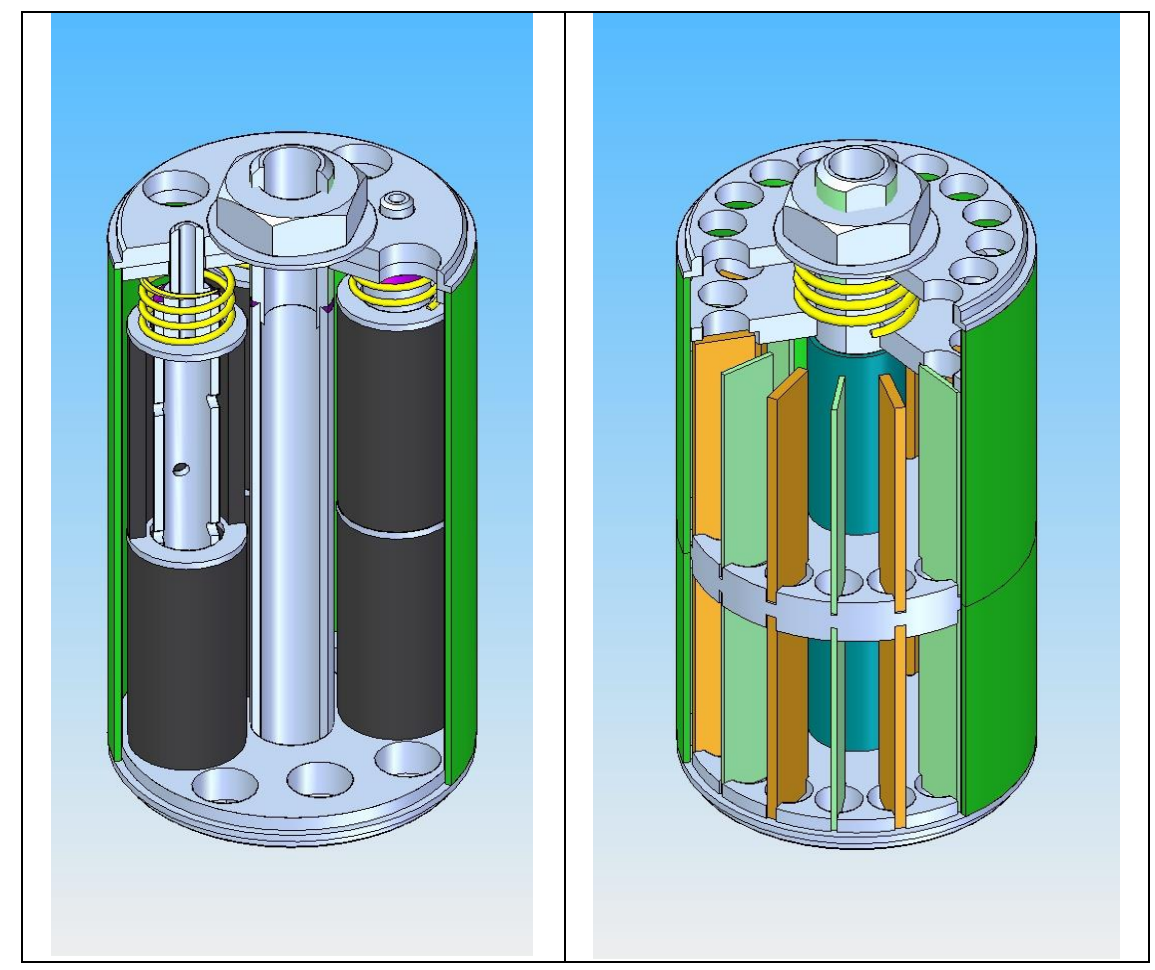

Figure 1 - Illustration of irradiation vehicles: Modules 3, 6, and 9 for tubular specimens (left) and Modules 4, 7, and 10 for coupon specimens (right). 


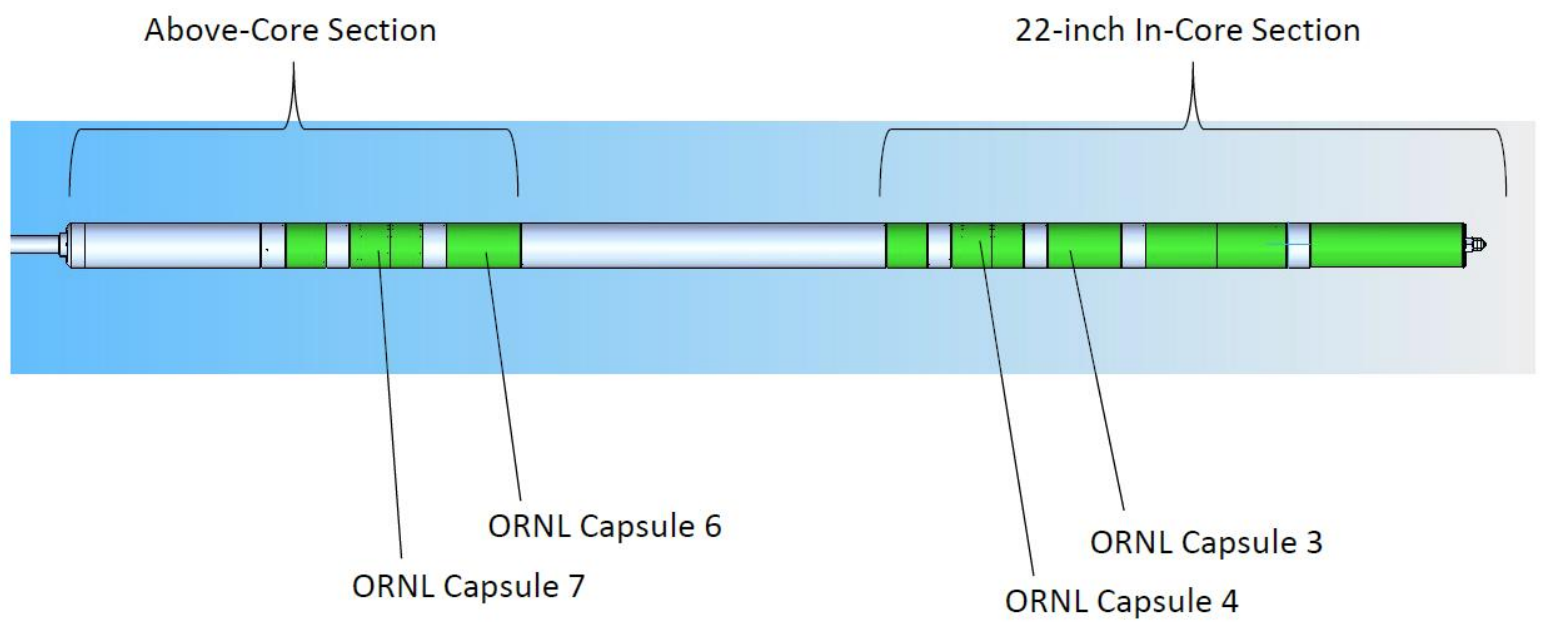

Figure 2 - COATI in- and above-core capsule locations within the autoclave stack

\subsection{Experiment Test Plan Materials}

A detailed listing of the specimen coupon and tube materials used in this study are provided in Appendix A. The test matrix includes nearly identical specimens in the three experiment positions (in-core, abovecore, and out-of-core). Table 2 summarizes the total number of specimens in each experiment location by specimen type. A total of 22 tubes and 96 coupons are being studied in the COATI experiment.

Table 2 - Specimen Summary by Location, Module and Type

\begin{tabular}{|c|c|c|c|}
\hline Location & Module & Specimen Type & Total \\
\hline Above-Core & 6 & Tube & 8 \\
\hline & 7 & Coupon & 32 \\
\hline Above-Core Total & & & 40 \\
\hline In-Core & 3 & Tube & 6 \\
\hline & 4 & Coupon & 32 \\
\hline In-Core Total & & & 38 \\
\hline Out-of-Core & 9 & Tube & 8 \\
\hline & 10 & Coupon & 32 \\
\hline Out-of-Core Total & & & 40 \\
\hline
\end{tabular}




\section{SUMMARY OF IRRADIATION RESULTS}

The COATI facility irradiation experiment operated for two cycles and was temporarily placed in dry storage between cycles. The first cycle started January 18, 2017 and ended on April 8, 2017. The second cycle started May 4, 2017 and ended on July 2, 2017. Several planned and un-planned reactor power changes occurred during these cycles and the loop was also shut down once in February due to a failing check-valve. MIT collected data on loop temperatures, pressure, flow, and reactor power throughout the experiment. Overall, the loop maintained constant temperature, pressure and flow whenever the reactor was operating. Statistics on cycles 1 and 2 are reported in Table 3. All ORNL capsules (3 and 4 in-core, 6 and 7 above-core, and 9 and 10 out-of-core) were exposed to the same temperature, pressure, and water flow. The times during which the autoclave was operating at the nominal temperature of $296^{\circ} \mathrm{C}$ are reported as "Hot Days." The neutron fluences that are reported are spatially averaged over the in-core region.

Table 3 - COATI Cycle Statistics

\begin{tabular}{|c|c|}
\hline \multicolumn{2}{|c|}{ Cycle 1 (1/18/17-4/8/17) } \\
\hline Elapsed Hours & 1921 \\
\hline Hot Days & 70 \\
\hline Integrated Reactor Power $\times$ Operating Time $(\mathrm{MWd})$ & 379 \\
\hline Fast Neutron Fluence $($ Energy $>0.1 \mathrm{MeV})\left(\mathrm{n} / \mathrm{cm}^{2}\right)$ & $6.77 \times 10^{20}$ \\
\hline Total Neutron Fluence $\left(\mathrm{n} / \mathrm{cm}^{2}\right)$ & $1.53 \times 10^{21}$ \\
\hline
\end{tabular}

\begin{tabular}{|c|c|}
\hline \multicolumn{2}{|c|}{ Cycle 2 (5/4/17-7/2/17) } \\
\hline Elapsed Hours & 1427 \\
\hline Hot Days & 57 \\
\hline Integrated Reactor Power $\times$ Operating Time $(\mathrm{MWd})$ & 295 \\
\hline Fast Neutron Fluence $($ Energy $>0.1 \mathrm{MeV})\left(\mathrm{n} / \mathrm{cm}^{2}\right)$ & $5.26 \times 10^{20}$ \\
\hline Total Neutron Fluence $\left(\mathrm{n} / \mathrm{cm}^{2}\right)$ & $1.19 \times 10^{21}$ \\
\hline
\end{tabular}

The position of the ORNL COATI capsules in relation to the centerline of the core directly impacts the fast and thermal neutron flux calculated for each capsule. Capsule 3 was placed between +1 inch and +4 inches above the core centerline. Capsule 4 was placed between +5 and +8 inches above the core centerline. The calculated average neutron fluence for each capsule are reported in Table 4 based on the capsule position and the calculated neutron flux spatial gradients in the core. 
Table 4 - Adjusted Neutron Fluence for ORNL Capsules

\begin{tabular}{|c|c|}
\hline \multicolumn{2}{|c|}{ Cycle 1 (1/18/17-4/8/17) } \\
\hline \multicolumn{2}{|c|}{ Capsule 3 } \\
\hline Fast Neutron Fluence (Energy $>0.1 \mathrm{MeV})\left(\mathrm{n} / \mathrm{cm}^{2}\right)$ & $6.08 \times 10^{20}$ \\
\hline Total Neutron Fluence $\left(\mathrm{n} / \mathrm{cm}^{2}\right)$ & $1.41 \times 10^{21}$ \\
\hline \multicolumn{2}{|c|}{ Capsule 4 } \\
\hline Fast Neutron Fluence (Energy $>0.1 \mathrm{MeV})\left(\mathrm{n} / \mathrm{cm}^{2}\right)$ & $4.70 \times 10^{20}$ \\
\hline Total Neutron Fluence $\left(\mathrm{n} / \mathrm{cm}^{2}\right)$ & $1.10 \times 10^{21}$ \\
\hline
\end{tabular}

\begin{tabular}{|c|c|}
\hline \multicolumn{2}{|c|}{ Cycle 2 (5/4/17-7/2/17) } \\
\hline \multicolumn{2}{|c|}{ Capsule 3 } \\
\hline Fast Neutron Fluence (Energy $>0.1 \mathrm{MeV})\left(\mathrm{n} / \mathrm{cm}^{2}\right)$ & $4.72 \times 10^{20}$ \\
\hline Total Neutron Fluence $\left(\mathrm{n} / \mathrm{cm}^{2}\right)$ & $1.09 \times 10^{21}$ \\
\hline \multicolumn{2}{|c|}{ Capsule 4} \\
\hline Fast Neutron Fluence (Energy $>0.1 \mathrm{MeV})\left(\mathrm{n} / \mathrm{cm}^{2}\right)$ & $3.64 \times 10^{20}$ \\
\hline Total Neutron Fluence $\left(\mathrm{n} / \mathrm{cm}^{2}\right)$ & $8.54 \times 10^{20}$ \\
\hline
\end{tabular}

After irradiation, the experiment was moved to dry storage at the MIT hot cell where it will be disassembled.

\section{FUTURE WORK}

The irradiated test specimens will be examined following capsule disassembly and shipped to an appropriate post-irradiation examination facility. Examination will include visual inspection and optical microscopy for evaluating the surface appearance and coating integrity. Other examinations will include dimensional and mass measurements as well as microstructural characterization and determination of micro-mechanical properties.

\section{REFERENCES}

[1] S.J. Zinkle, K.A. Terrani, J.C. Gehin, L.J. Ott, L.L. Snead, Accident tolerant fuels for LWRs: A perspective, J. Nucl. Mater. 448 (2014) 374-379.

[2] Y. Katoh, L.L. Snead, I. Szlufarska, W.J. Weber, Radiation Effects in SiC for Nuclear Structural Applications, Curr. Opin. Solid State Mater. Sci. 16 (2012) 143-152. doi:http://dx.doi.org/10.1016/j.cossms.2012.03.005.

[3] K.A. Terrani, B.A. Pint, C.M. Parish, C.M. Silva, L.L. Snead, Y. Katoh, Silicon carbide oxidation in steam up to $2 \mathrm{MPa}$, J. Am. Ceram. Soc. 97 (2014) 2331-2352. doi:10.1111/jace.13094.

[4] S. Bragg-Sitton, D. Hurley, M. Khafizov, B. Merrill, R. Schley, K. McHugh, I. van Rooyen, Y. Katoh, C. Shih, Silicon Carbide Gap Analysis and Feasibility Study, INL/EXT-13-29728, Idaho National Laboratory, Idaho Falls, 2013. 
[5] Y. Katoh, K.A. Terrani, Systematic Technology Evaluation Program for SiC/SiC Composite-based Accident-Tolerant LWR Fuel Cladding and Core Structures: Revision 2015, ORNL/TM-2015/454, Oak Ridge National Laboratory, 2015.

[6] J.D. Stempien, D.M. Carpenter, G. Kohse, M.S. Kazimi, Characteristics of Composite Silicon Carbide Fuel Cladding After Irradiation Under Simulated Pwr Conditions Nuclear Systems, Nucl. Technol. 183 (2013) 13-29. doi:10.13182/NT12-86.

[7] C. Science, Massachusetts Institute of Technology Massachusetts Institute of Technology, (2011) 1-2. https://nrl.mit.edu/reactor (accessed September 8, 2017). 


\section{APPENDIX A}

\begin{tabular}{|c|c|c|c|c|c|c|c|}
\hline Module & Location & Layer & Position & $\begin{array}{c}\text { Specimen } \\
\text { Type }\end{array}$ & Material Class & Base Material & Coating Material \\
\hline 3 & In-Core & 1 & $\mathrm{c}$ & Tube & Coated SiC/SiC & GA HNS/CVI & PVD ZrN(1-x) \\
\hline 3 & In-Core & 1 & $\mathrm{~d}$ & Tube & Coated SiC/SiC & GA HNS/CVI & UWM Zr-Si \\
\hline 3 & In-Core & 2 & $\mathrm{e}$ & Tube & Coated SiC/SiC & GA HNS/CVI & PVD CrN(1-x)-Cr2N \\
\hline 3 & In-Core & 2 & $\mathrm{f}$ & Tube & SiC/SiC & GA HNS/CVI & (none) \\
\hline 3 & In-Core & 2 & $\mathrm{~g}$ & Tube & Coated SiC/SiC & GA HNS/CVI & PVD TiN \\
\hline 3 & In-Core & 2 & $\mathrm{~h}$ & Tube & FeCrAl & C36M3 & (none) \\
\hline 4 & In-Core & 1 & $\mathrm{a}$ & Coupon & Monolithic & CT HP SiC & (none) \\
\hline 4 & In-Core & 1 & $\mathrm{~b}$ & Coupon & Monolithic & CT CVD SiC HR & (none) \\
\hline 4 & In-Core & 1 & $\mathrm{c}$ & Coupon & Monolithic & CT HP SiC & (none) \\
\hline 4 & In-Core & 1 & $\mathrm{~d}$ & Coupon & Monolithic & CT CVD SiC HR & (none) \\
\hline 4 & In-Core & 1 & $\mathrm{e}$ & Coupon & Monolithic & CT HP SiC & PVD Cr \\
\hline 4 & In-Core & 1 & $\mathrm{f}$ & Coupon & Monolithic & CT CVD SiC LR & (none) \\
\hline 4 & In-Core & 1 & $\mathrm{~h}$ & Coupon & Monolithic & CT CVD SiC LR & (none) \\
\hline 4 & In-Core & 1 & $\mathrm{i}$ & Coupon & Monolithic & NITE SiC-YAG & PVD Cr \\
\hline 4 & In-Core & 1 & $\mathrm{j}$ & Coupon & Coated SiC & R\&H CVD SiC & HR \\
\hline
\end{tabular}




\begin{tabular}{|c|c|c|c|c|c|c|c|}
\hline Module & Location & Layer & Position & $\begin{array}{c}\text { Specimen } \\
\text { Type }\end{array}$ & Material Class & Base Material & Coating Material \\
\hline 4 & In-Core & 1 & $\mathrm{~m}$ & Coupon & Coated SiC & $\begin{array}{c}\text { R\&H CVD SiC } \\
\text { HR }\end{array}$ & EP PyC-Cr \\
\hline 4 & In-Core & 1 & $\mathrm{n}$ & Coupon & Coated SiC & $\begin{array}{c}\text { R\&H CVD SiC } \\
\text { HR }\end{array}$ & PVD TiN(1-x) \\
\hline 4 & In-Core & 1 & $\mathrm{o}$ & Coupon & Coated SiC & $\begin{array}{c}\text { R\&H CVD SiC } \\
\text { HR }\end{array}$ & EP Ni-Cr \\
\hline 4 & In-Core & 1 & $\mathrm{p}$ & Coupon & Monolithic & $\begin{array}{c}\text { R\&H CVD SiC } \\
\text { HR }\end{array}$ & (none) \\
\hline 4 & In-Core & 2 & $\mathrm{q}$ & Coupon & Coated SiC & $\begin{array}{c}\text { R\&H CVD SiC } \\
\text { HR }\end{array}$ & EP Ni-Cr \\
\hline 4 & In-Core & 2 & $\mathrm{r}$ & Coupon & Monolithic & $\begin{array}{c}\text { R\&H CVD SiC } \\
\text { HR }\end{array}$ & (none) \\
\hline 4 & In-Core & 2 & $\mathrm{~s}$ & Coupon & Coated SiC & $\begin{array}{c}\text { R\&H CVD SiC } \\
\text { HR }\end{array}$ & $\mathrm{EP} \mathrm{Ni-Cr}$ \\
\hline 4 & In-Core & 2 & $\mathrm{t}$ & Coupon & Monolithic & Cree 6H-SiC & (none) \\
\hline 4 & In-Core & 2 & $\mathrm{u}$ & Coupon & Coated $\mathrm{SiC}$ & $\begin{array}{c}\text { R\&H CVD SiC } \\
\text { HR }\end{array}$ & UWM Zr-Si \\
\hline 4 & In-Core & 2 & $\mathrm{v}$ & Coupon & Monolithic & $\mathrm{Cr}$ & (none) \\
\hline 4 & In-Core & 2 & $\mathrm{w}$ & Coupon & Coated SiC & $\begin{array}{c}\text { R\&H CVD SiC } \\
\text { HR }\end{array}$ & $\operatorname{PVD} \operatorname{ZrN}(1-\mathrm{x})$ \\
\hline 4 & In-Core & 2 & $\mathrm{x}$ & Coupon & $\mathrm{FeCrAl}$ & Kanthal AF & (none) \\
\hline 4 & In-Core & 2 & $\mathrm{y}$ & Coupon & $\mathrm{FeCrAl}$ & $\mathrm{C} 06 \mathrm{M}$ & (none) \\
\hline 4 & In-Core & 2 & $\mathrm{z}$ & Coupon & $\mathrm{FeCrAl}$ & Kanthal AF & (none) \\
\hline 4 & In-Core & 2 & aa & Coupon & $\mathrm{FeCrAl}$ & $\mathrm{C} 06 \mathrm{M}$ & (none) \\
\hline 4 & In-Core & 2 & $a b$ & Coupon & Zr alloy & Zircaloy-4 & (none) \\
\hline 4 & In-Core & 2 & $\mathrm{ac}$ & Coupon & $\mathrm{FeCrAl}$ & C36M & (none) \\
\hline 4 & In-Core & 2 & $\mathrm{ad}$ & Coupon & Zr alloy & Zircaloy-4 & (none) \\
\hline 4 & In-Core & 2 & ae & Coupon & $\mathrm{FeCrAl}$ & $\mathrm{C} 36 \mathrm{M}$ & (none) \\
\hline 4 & In-Core & 2 & af & Coupon & Monolithic & Cree 6H-SiC & (none) \\
\hline
\end{tabular}




\begin{tabular}{|c|c|c|c|c|c|c|c|}
\hline Module & Location & Layer & Position & $\begin{array}{c}\text { Specimen } \\
\text { Type }\end{array}$ & Material Class & Base Material & Coating Material \\
\hline 6 & Above-Core & 1 & $\mathrm{a}$ & Tube & $\mathrm{FeCrAl}$ & $\mathrm{C} 36 \mathrm{M} 3$ & (none) \\
\hline 6 & Above-Core & 1 & $\mathrm{~b}$ & Tube & $\mathrm{FeCrAl}$ & $\mathrm{B} 136 \mathrm{Y}$ & (none) \\
\hline 6 & Above-Core & 1 & $\mathrm{c}$ & Tube & Coated $\mathrm{SiC} / \mathrm{SiC}$ & GA HNS/CVI & $\mathrm{EP} \mathrm{Ni}-\mathrm{Cr}$ \\
\hline 6 & Above-Core & 1 & $\mathrm{~d}$ & Tube & Coated $\mathrm{SiC} / \mathrm{SiC}$ & GA HNS/CVI & $\operatorname{PVD} \mathrm{CrN}(1-\mathrm{x})-\mathrm{Cr} 2 \mathrm{~N}$ \\
\hline 6 & Above-Core & 2 & $\mathrm{e}$ & Tube & Coated $\mathrm{SiC} / \mathrm{SiC}$ & GA HNS/CVI & PVD TiN(1-x) \\
\hline 6 & Above-Core & 2 & $\mathrm{f}$ & Tube & $\mathrm{SiC} / \mathrm{SiC}$ & GA HNS/CVI & (none) \\
\hline 6 & Above-Core & 2 & $\mathrm{~g}$ & Tube & Coated $\mathrm{SiC} / \mathrm{SiC}$ & GA HNS/CVI & $\operatorname{PVD} \operatorname{ZrN}(1-x)$ \\
\hline 6 & Above-Core & 2 & $\mathrm{~h}$ & Tube & Zr alloy & Zircaloy-4 & (none) \\
\hline 7 & Above-Core & 1 & $\mathrm{a}$ & Coupon & Coated SiC & CT HP SiC & PVD CrN \\
\hline 7 & Above-Core & 1 & $\mathrm{~b}$ & Coupon & Coated $\mathrm{SiC}$ & $\begin{array}{c}\text { R\&H CVD SiC } \\
\text { HR } \\
\end{array}$ & $\operatorname{PVD} \mathrm{CrN}(1-\mathrm{x})-\mathrm{Cr} 2 \mathrm{~N}$ \\
\hline 7 & Above-Core & 1 & $\mathrm{c}$ & Coupon & Coated $\mathrm{SiC}$ & CT HP SiC & PVD Cr2N \\
\hline 7 & Above-Core & 1 & $\mathrm{~d}$ & Coupon & Coated $\mathrm{SiC}$ & $\begin{array}{c}\text { R\&H CVD SiC } \\
\text { HR }\end{array}$ & $\mathrm{PVD} \mathrm{Cr}$ \\
\hline 7 & Above-Core & 1 & $\mathrm{e}$ & Coupon & Monolithic & CT HP SiC & (none) \\
\hline 7 & Above-Core & 1 & $\mathrm{f}$ & Coupon & Coated SiC & $\begin{array}{c}\text { R\&H CVD SiC } \\
\text { HR }\end{array}$ & PVD TiN(1-x) \\
\hline 7 & Above-Core & 1 & $\mathrm{~g}$ & Coupon & Coated SiC & $\begin{array}{c}\text { R\&H CVD SiC } \\
\text { HR }\end{array}$ & $\mathrm{EP} \mathrm{Ni}-\mathrm{Cr}$ \\
\hline 7 & Above-Core & 1 & $\mathrm{~h}$ & Coupon & Monolithic & Cree 6H-SiC & (none) \\
\hline 7 & Above-Core & 1 & $\mathrm{i}$ & Coupon & Coated $\mathrm{SiC}$ & $\begin{array}{c}\text { R\&H CVD SiC } \\
\text { HR }\end{array}$ & EP Cr2Si-Ni2Si \\
\hline 7 & Above-Core & 1 & $\mathrm{j}$ & Coupon & Monolithic & CT CVD SiC LR & (none) \\
\hline 7 & Above-Core & 1 & $\mathrm{k}$ & Coupon & Coated $\mathrm{SiC}$ & $\begin{array}{c}\text { R\&H CVD SiC } \\
\text { HR } \\
\end{array}$ & EP PyC-Cr \\
\hline 7 & Above-Core & 1 & 1 & Coupon & Monolithic & CT CVD SiC LR & (none) \\
\hline 7 & Above-Core & 1 & $\mathrm{~m}$ & Coupon & Coated SiC & $\begin{array}{c}\text { R\&H CVD SiC } \\
\text { HR }\end{array}$ & EP Ni-Cr \\
\hline
\end{tabular}




\begin{tabular}{|c|c|c|c|c|c|c|c|}
\hline Module & Location & Layer & Position & $\begin{array}{c}\text { Specimen } \\
\text { Type }\end{array}$ & Material Class & Base Material & Coating Material \\
\hline 7 & Above-Core & 1 & $\mathrm{n}$ & Coupon & Monolithic & CT CVD SiC HR & (none) \\
\hline 7 & Above-Core & 1 & o & Coupon & Coated SiC & $\begin{array}{c}\text { R\&H CVD SiC } \\
\text { HR }\end{array}$ & $\mathrm{EP} \mathrm{Ni}-\mathrm{Cr}$ \\
\hline 7 & Above-Core & 1 & $\mathrm{p}$ & Coupon & Monolithic & CT CVD SiC HR & (none) \\
\hline 7 & Above-Core & 2 & $q$ & Coupon & Coated SiC & $\begin{array}{c}\text { R\&H CVD SiC } \\
\text { HR }\end{array}$ & UWM Zr-Si \\
\hline 7 & Above-Core & 2 & $\mathrm{r}$ & Coupon & Monolithic & $\begin{array}{c}\text { R\&H CVD SiC } \\
\text { HR }\end{array}$ & (none) \\
\hline 7 & Above-Core & 2 & $\mathrm{~s}$ & Coupon & Monolithic & NITE SiC-YAG & (none) \\
\hline 7 & Above-Core & 2 & $\mathrm{t}$ & Coupon & Monolithic & $\begin{array}{c}\text { R\&H CVD SiC } \\
\text { HR }\end{array}$ & (none) \\
\hline 7 & Above-Core & 2 & $\mathrm{u}$ & Coupon & Coated $\mathrm{SiC} / \mathrm{SiC}$ & HHTC SA3/CVI & $\mathrm{PVD} \mathrm{Cr}$ \\
\hline 7 & Above-Core & 2 & $\mathrm{v}$ & Coupon & Coated $\mathrm{SiC}$ & $\mathrm{R} \& \mathrm{H}$ CVD SiC & PVD Cr \\
\hline 7 & Above-Core & 2 & $\mathrm{w}$ & Coupon & Coated SiC & $\begin{array}{c}\text { R\&H CVD SiC } \\
\text { HR }\end{array}$ & $\operatorname{PVD} \operatorname{ZrN}(1-\mathrm{x})$ \\
\hline 7 & Above-Core & 2 & $\mathrm{x}$ & Coupon & $\mathrm{FeCrAl}$ & Kanthal AF & (none) \\
\hline 7 & Above-Core & 2 & $\mathrm{y}$ & Coupon & $\mathrm{FeCrAl}$ & $\mathrm{C} 06 \mathrm{M}$ & (none) \\
\hline 7 & Above-Core & 2 & $\mathrm{z}$ & Coupon & $\mathrm{FeCrAl}$ & Kanthal AF & (none) \\
\hline 7 & Above-Core & 2 & aa & Coupon & $\mathrm{FeCrAl}$ & $\mathrm{C} 06 \mathrm{M}$ & (none) \\
\hline 7 & Above-Core & 2 & $a b$ & Coupon & Zr alloy & Zircaloy-4 & (none) \\
\hline 7 & Above-Core & 2 & $\mathrm{ac}$ & Coupon & $\mathrm{FeCrAl}$ & $\mathrm{C} 36 \mathrm{M}$ & (none) \\
\hline 7 & Above-Core & 2 & $\mathrm{ad}$ & Coupon & Zr alloy & Zircaloy-4 & (none) \\
\hline 7 & Above-Core & 2 & ae & Coupon & $\mathrm{FeCrAl}$ & $\mathrm{C} 36 \mathrm{M}$ & (none) \\
\hline 7 & Above-Core & 2 & af & Coupon & Coated SiC & $\begin{array}{c}\text { R\&H CVD SiC } \\
\text { HR }\end{array}$ & $\operatorname{PVD} \operatorname{CrN}(1-\mathrm{x})$ \\
\hline 9 & Out-of-Core & 1 & $\mathrm{a}$ & Tube & $\mathrm{FeCrAl}$ & $\mathrm{C} 36 \mathrm{M} 3$ & (none) \\
\hline 9 & Out-of-Core & 1 & $\mathrm{~b}$ & Tube & $\mathrm{FeCrAl}$ & $\mathrm{B} 136 \mathrm{Y}$ & (none) \\
\hline
\end{tabular}




\begin{tabular}{|c|c|c|c|c|c|c|c|}
\hline Module & Location & Layer & Position & $\begin{array}{c}\text { Specimen } \\
\text { Type }\end{array}$ & Material Class & Base Material & Coating Material \\
\hline 9 & Out-of-Core & 1 & $\mathrm{c}$ & Tube & Coated $\mathrm{SiC} / \mathrm{SiC}$ & GA HNS/CVI & $\mathrm{EP} \mathrm{Ni}-\mathrm{Cr}$ \\
\hline 9 & Out-of-Core & 1 & $\mathrm{~d}$ & Tube & Coated $\mathrm{SiC} / \mathrm{SiC}$ & GA HNS/CVI & $\operatorname{PVD} \mathrm{CrN}(1-\mathrm{x})-\mathrm{Cr} 2 \mathrm{~N}$ \\
\hline 9 & Out-of-Core & 2 & $\mathrm{e}$ & Tube & Coated $\mathrm{SiC} / \mathrm{SiC}$ & GA HNS/CVI & PVD TiN $(1-x)$ \\
\hline 9 & Out-of-Core & 2 & $\mathrm{f}$ & Tube & $\mathrm{SiC} / \mathrm{SiC}$ & GA HNS/CVI & (none) \\
\hline 9 & Out-of-Core & 2 & $\mathrm{~g}$ & Tube & Coated $\mathrm{SiC} / \mathrm{SiC}$ & GA HNS/CVI & PVD ZrN(1-x) \\
\hline 9 & Out-of-Core & 2 & $\mathrm{~h}$ & Tube & Zr alloy & Zircaloy-4 & (none) \\
\hline 10 & Out-of-Core & 1 & $\mathrm{a}$ & Coupon & Monolithic & CT HP SiC & (none) \\
\hline 10 & Out-of-Core & 1 & $\mathrm{~b}$ & Coupon & Coated SiC & $\begin{array}{c}\text { R\&H CVD SiC } \\
\text { HR }\end{array}$ & $\operatorname{PVD} \mathrm{CrN}(1-\mathrm{x})-\mathrm{Cr} 2 \mathrm{~N}$ \\
\hline 10 & Out-of-Core & 1 & $\mathrm{c}$ & Coupon & Coated SiC & CT HP SiC & PVD Cr2N \\
\hline 10 & Out-of-Core & 1 & $\mathrm{~d}$ & Coupon & Coated SiC & $\begin{array}{c}\text { R\&H CVD SiC } \\
\text { HR }\end{array}$ & PVD Cr \\
\hline 10 & Out-of-Core & 1 & $\mathrm{e}$ & Coupon & Monolithic & CT HP SiC & PVD TiN \\
\hline 10 & Out-of-Core & 1 & $\mathrm{f}$ & Coupon & Coated SiC & $\begin{array}{c}\text { R\&H CVD SiC } \\
\text { HR }\end{array}$ & PVD TiN(1-x) \\
\hline 10 & Out-of-Core & 1 & $\mathrm{~g}$ & Coupon & Coated SiC & $\begin{array}{c}\text { R\&H CVD SiC } \\
\text { HR }\end{array}$ & EP Ni-Cr \\
\hline 10 & Out-of-Core & 1 & $\mathrm{~h}$ & Coupon & Monolithic & Cree 6H-SiC & (none) \\
\hline 10 & Out-of-Core & 1 & $\mathrm{i}$ & Coupon & Coated SiC & $\begin{array}{c}\text { R\&H CVD SiC } \\
\text { HR }\end{array}$ & EP Cr2Si-Ni2Si \\
\hline 10 & Out-of-Core & 1 & $\mathrm{j}$ & Coupon & Monolithic & CT CVD SiC LR & (none) \\
\hline 10 & Out-of-Core & 1 & $\mathrm{k}$ & Coupon & Coated SiC & $\begin{array}{c}\text { R\&H CVD SiC } \\
\text { HR }\end{array}$ & EP PyC-Cr \\
\hline 10 & Out-of-Core & 1 & 1 & Coupon & Monolithic & CT CVD SiC LR & (none) \\
\hline 10 & Out-of-Core & 1 & $\mathrm{~m}$ & Coupon & Coated SiC & $\begin{array}{c}\text { R\&H CVD SiC } \\
\text { HR }\end{array}$ & $\mathrm{EP} \mathrm{Ni}-\mathrm{Cr}$ \\
\hline 10 & Out-of-Core & 1 & $\mathrm{n}$ & Coupon & Monolithic & CT CVD SiC HR & (none) \\
\hline
\end{tabular}




\begin{tabular}{|c|c|c|c|c|c|c|c|}
\hline Module & Location & Layer & Position & $\begin{array}{c}\text { Specimen } \\
\text { Type }\end{array}$ & Material Class & Base Material & Coating Material \\
\hline 10 & Out-of-Core & 1 & o & Coupon & Coated SiC & $\begin{array}{c}\text { R\&H CVD SiC } \\
\text { HR }\end{array}$ & $\mathrm{EP} \mathrm{Ni-Cr}$ \\
\hline 10 & Out-of-Core & 1 & $\mathrm{p}$ & Coupon & Monolithic & CT CVD SiC HR & (none) \\
\hline 10 & Out-of-Core & 2 & $\mathrm{q}$ & Coupon & Coated $\mathrm{SiC} / \mathrm{SiC}$ & HHTC SA3/CVI & UWM Zr-Si \\
\hline 10 & Out-of-Core & 2 & $\mathrm{r}$ & Coupon & Monolithic & $\begin{array}{c}\text { R\&H CVD SiC } \\
\text { HR }\end{array}$ & (none) \\
\hline 10 & Out-of-Core & 2 & $\mathrm{~s}$ & Coupon & Monolithic & NITE SiC-YAG & (none) \\
\hline 10 & Out-of-Core & 2 & $\mathrm{t}$ & Coupon & Monolithic & $\begin{array}{c}\text { R\&H CVD SiC } \\
\text { HR }\end{array}$ & (none) \\
\hline 10 & Out-of-Core & 2 & $\mathrm{u}$ & Coupon & Coated $\mathrm{SiC} / \mathrm{SiC}$ & HHTC SA3/CVI & PVD Cr \\
\hline 10 & Out-of-Core & 2 & $\mathrm{v}$ & Coupon & Monolithic & $\mathrm{Cr}$ & (none) \\
\hline 10 & Out-of-Core & 2 & $\mathrm{w}$ & Coupon & Coated SiC & $\begin{array}{c}\text { R\&H CVD SiC } \\
\text { HR }\end{array}$ & $\operatorname{PVD} \operatorname{ZrN}(1-\mathrm{x})$ \\
\hline 10 & Out-of-Core & 2 & $\mathrm{x}$ & Coupon & $\mathrm{FeCrAl}$ & Kanthal AF & (none) \\
\hline 10 & Out-of-Core & 2 & $\mathrm{y}$ & Coupon & $\mathrm{FeCrAl}$ & $\mathrm{C} 06 \mathrm{M}$ & (none) \\
\hline 10 & Out-of-Core & 2 & $\mathrm{z}$ & Coupon & $\mathrm{FeCrAl}$ & Kanthal AF & (none) \\
\hline 10 & Out-of-Core & 2 & aa & Coupon & $\mathrm{FeCrAl}$ & $\mathrm{C} 06 \mathrm{M}$ & (none) \\
\hline 10 & Out-of-Core & 2 & $a b$ & Coupon & Zr alloy & Zircaloy-4 & (none) \\
\hline 10 & Out-of-Core & 2 & $\mathrm{ac}$ & Coupon & $\mathrm{FeCrAl}$ & $\mathrm{C} 36 \mathrm{M}$ & (none) \\
\hline 10 & Out-of-Core & 2 & $\mathrm{ad}$ & Coupon & Zr alloy & Zircaloy-4 & (none) \\
\hline 10 & Out-of-Core & 2 & ae & Coupon & $\mathrm{FeCrAl}$ & $\mathrm{C} 36 \mathrm{M}$ & (none) \\
\hline 10 & Out-of-Core & 2 & af & Coupon & Coated $\mathrm{SiC}$ & $\begin{array}{c}\text { R\&H CVD SiC } \\
\text { HR }\end{array}$ & $\operatorname{PVD} \mathrm{CrN}(1-\mathrm{x})-\mathrm{Cr} 2 \mathrm{~N}$ \\
\hline
\end{tabular}

